\title{
Structural Characterization of a Base-Stabilized $\left[Z_{2}\right]^{2+}$ Dication**
}

\author{
Stephan Schulz, * Daniella Schuchmann, Ingo Krossing, * Daniel Himmel, Dieter Bläser und Roland \\ Boese
}

Dedicated to Prof. Dr. M. Jansen on the occasion of his 65th birthday

The landmark discovery of decamethyldizincocene $\mathrm{Cp}^{*}{ }_{2} \mathrm{Zn}_{2} 1$ by Carmona et al. in $2004^{[1]}$ has led to increasing research activities on the synthesis of low-valent metal complexes of group 2 and 12 metals in recent years and several complexes containing $\mathrm{Mg}-\mathrm{Mg}^{[2]}$, $\mathrm{Cd}-\mathrm{Cd}^{[3,4]}, \mathrm{Hg}-\mathrm{Hg}^{[4]}$ and $\mathrm{Zn}-\mathrm{Zn}^{[5-11]}$ bonds, which are typically kinetically stabilized by use of sterically demanding or chelating organic substituents, have been synthesized. However, it should be noted that the first molecular complex with a $\mathrm{Zn}-\mathrm{Zn}$ bond, $\mathrm{Zn}_{2} \mathrm{H}_{2}$, was trapped in an Ar matrix at $12 \mathrm{~K}$ and characterized by vibrational spectroscopy and computational calculations. ${ }^{[12]}$ With respect to the rather large number of organometallic complexes containing a direct $\mathrm{Zn}-\mathrm{Zn}$ bond it is somehow surprising, that only a single study proves the existence of a $\left[\mathrm{Zn}_{2}\right]^{2+}$ dication, which was obtained in a melt of $\mathrm{Zn}$ in $\mathrm{ZnCl}_{2}$ and characterized by Raman spectroscopy. ${ }^{[13]}$ This is in remarkable contrast to the well known $\left[\mathrm{Hg}_{2}\right]^{2+}$ and $\left[\mathrm{Cd}_{2}\right]^{2+}$ dications and has been subject to several computational investigations. ${ }^{[14]}$ In addition, a very few reports demonstrated the presence of $[\mathrm{Zn}]^{+}$ cations in microporous materials. ${ }^{[15]}$

Recently, we became interested not only in the synthesis but also in the reactivity of low-valent organozinc complexes. Our initial studies focused on reactions of $\mathrm{Cp}^{*}{ }_{2} \mathrm{Zn}_{2} \mathbf{1}$ due to the promising steric and electronic flexibility of the $\mathrm{Cp}^{*}$ substituent. ${ }^{[16]}$ The reaction with 4-dimethylamino pyridine (dmap), which has been previously shown in our group to be a valuable Lewis base for the synthesis of base-stabilized monomeric group 13/15 compounds, ${ }^{[17]}$ resulted in the formation of $\mathrm{Cp} * \mathrm{Zn}-\mathrm{Zn}$ (dmap) ${ }_{2} \mathrm{Cp}^{*}$ $2{ }^{[18]}$ in which the dmap molecules bind in a geminal coordination mode to only a single $\mathrm{Zn}$ atom. Disproportionation reaction into elemental zinc and the corresponding $\mathrm{Zn}$ (II) compound, as was previously observed in reactions of $\mathbf{1}$ with Lewis bases, did not occur. ${ }^{[1,5]}$ At the same time, low valent organomagnesium(I)

[*] Prof. S. Schulz. D. Schuchmann, D. Bläser, Prof. R. Boese Inorganic Chemistry, University of Duisburg-Essen Universitätsstr. 5-7, S07 S03 C30, D-45117 Essen Fax: (+) 201-183 3830

E-mail: stephan.schulz@uni-due.de

Homepage: http://www.uni-due.de/ak_schulz/index.php

Prof. I. Krossing, Dr. D. Himmel

Inorganic and Analytical Chemistry, University Freiburg Albertstr. 21, D-79104 Freiburg i. Br.

[**] S. Schulz and I. Krossing thank the German Science Foundation (DFG) for financial support. D. Schuchmann is grateful to the Fonds der Chemischen Industrie for a doctoral fellowship. Prof. H.-W. Siesler, University of Duisburg-Essen, is gratefully acknowledged for the measurement of the Raman spectra.

Supporting information for this article is available on the WWW under http://www.angewandte.org or from the author. complexes were found to react with Lewis bases with subsequent formation of the vicinal coordinated adducts. ${ }^{[19]}$ Moreover, we reported on the reaction of $\mathbf{1}$ with $[\{(2,4,6-$ $\left.\left.\left.\mathrm{Me}_{3} \mathrm{C}_{6} \mathrm{H}_{2}\right) \mathrm{N}(\mathrm{Me}) \mathrm{C}\right\}_{2} \mathrm{CH}\right] \mathrm{H}$ (MesnacnacH), which proceeded with protonation of the $\mathrm{Cp}^{*}$ substituent and subsequent formation of the new $\mathrm{Zn}-\mathrm{Zn}$ bonded complex Mesnacnac $2 \mathrm{Zn}_{2}$ 3. $^{[20]}$

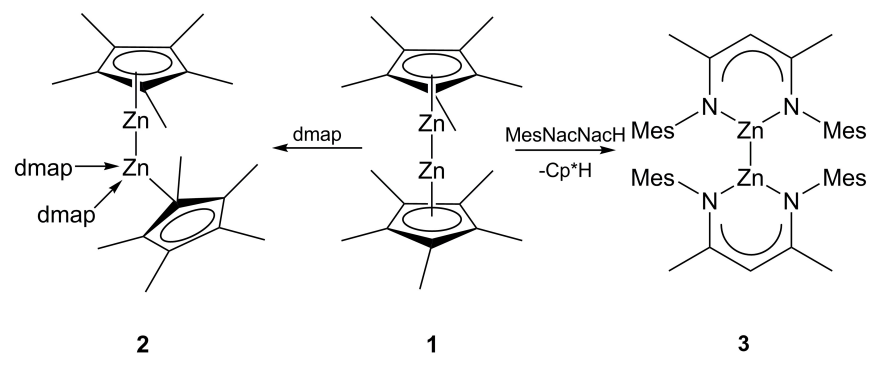

Scheme 1. Reactions of $\mathrm{Cp}^{*}{ }_{2} \mathrm{Zn}_{2} 1$.

In order to elucidate, if this specific reaction might give a general access to low-valent organozinc complexes, we began to investigate the reaction of both $\mathbf{1}$ and $\mathbf{2}$ with protonating reagents. Herein, we report on the reaction of $\mathbf{2}$ with

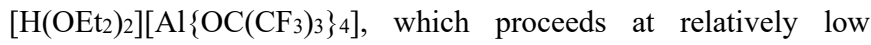
temperature with elimination of $\mathrm{Cp} * \mathrm{H}$ and subsequent formation of $\left[\mathrm{Zn}_{2}(\mathrm{dmap})_{6}\right]\left[\mathrm{Al}\left\{\mathrm{OC}\left(\mathrm{CF}_{3}\right)_{3}\right\}_{4}\right]_{2} \quad 4$ containing the base-stabilized $\left[\mathrm{Zn}_{2}\right]^{2+}$ dication.

$\mathrm{Cp}_{2}{ }_{2} \mathrm{Zn}_{2}(\mathrm{dmap})_{2} \frac{2\left[\mathrm{H}\left(\mathrm{OEt}_{2}\right)_{2}\right]\left[\mathrm{A} \mid\left\{\mathrm{OC}\left(\mathrm{CF}_{3}\right)_{3}\right\}_{4}\right]}{-2 \mathrm{Cp}^{*} \mathrm{H}}\left[\mathrm{Zn}_{2}(\mathrm{dmap})_{6}\right]\left[\mathrm{Al}\left\{\mathrm{OC}\left(\mathrm{CF}_{3}\right)_{3}\right\}_{4}\right]_{2}$

\section{Scheme 2. Synthesis of $\left[\mathrm{Zn}_{2}(\mathrm{dmap})_{6}\right]\left[\mathrm{Al}\left\{\mathrm{OC}\left(\mathrm{CF}_{3}\right)_{3}\right\}_{4}\right]_{2} 4$}

A solution of 2 in $\mathrm{CH}_{2} \mathrm{Cl}_{2}$ reacts with two equivalents of $\left[\mathrm{H}\left(\mathrm{OEt}_{2}\right)_{2}\right]\left[\mathrm{Al}\left\{\mathrm{OC}_{(}\left(\mathrm{CF}_{3}\right)_{3}\right\}_{4}\right]$ at $-30{ }^{\circ} \mathrm{C}$ with formation of $\mathbf{4}$, which was isolated after crystallization at $-30{ }^{\circ} \mathrm{C}$ as a colorless crystalline solid. NMR spectra $\left({ }^{1} \mathrm{H},{ }^{13} \mathrm{C},{ }^{19} \mathrm{~F}\right)$ of $\mathbf{4}$ show resonances only due to the dmap group and the aluminate anion, whereas no indication for the presence of a $\mathrm{Cp}^{*}$ group was found. ${ }^{[21]}$ Single crystals of $\mathbf{4}$ were obtained from a solution in $\mathrm{CH}_{2} \mathrm{Cl}_{2}$ upon storage at $-30{ }^{\circ} \mathrm{C}$. ${ }^{[22]} 4$ consists of a base stabilized $\left[\mathrm{Zn}_{2}(\mathrm{dmap})_{6}\right]^{2+}$ dication and two $\left[\mathrm{Al}\left\{\mathrm{OC}\left(\mathrm{CF}_{3}\right)_{3}\right\}_{4}\right]^{-}$anions. The $\mathrm{Zn}$ atoms adopt tetrahedral coordination spheres with the $\mathrm{Zn}-\mathrm{N}$ bond distances (2.136(5) $\AA$ ) slightly elongated compared to those in 2 (2.115(2), 2.125(2) $\AA$ ). The central $\mathrm{Zn}-\mathrm{Zn}$ bond distance of $2.419(1) \AA$ atom is almost identical to that reported for $2(2.418(1) \AA)$, whereas $Z_{2} R_{2}$ complexes typically show shorter $\mathrm{Zn}-\mathrm{Zn}$ bond distances, ranging from 2.29 to $2.35 \AA$. Only 3 (R = Mesnacnac, 2.3813(8) $\AA$ ) and the doubly-reduced diimine derivative $\left(\mathrm{R}=\left[\left(2,6-i-\mathrm{Pr}_{2} \mathrm{C}_{6} \mathrm{H}_{3}\right) \mathrm{N}(\mathrm{Me}) \mathrm{C}\right]_{2}\right.$, 2.3994(6) $\AA)^{[8]}$ show comparable $\mathrm{Zn}-\mathrm{Zn}$ bond lengths. The 
$\left[\mathrm{Al}\left\{\mathrm{OC}\left(\mathrm{CF}_{3}\right)_{3}\right\}_{4}\right]^{-}$anion is disordered. ${ }^{[23]}$ Theoretical calculations of 4 at BP86/def-SV(P) niveau revealed a gas phase minimum structure $4^{\prime}$ with $\mathrm{S}_{6}$ symmetry. ${ }^{[24]}$ An alternative structure with the $\mathrm{Zn}$ atoms connected by two bridging $\mathrm{H}$-atoms was unstable and split into separated (dmap) $\mathrm{ZnH}^{+}$cations during the geometry optimization. The calculated $\mathrm{Zn}-\mathrm{Zn}(2.399 \AA)$ and $\mathrm{Zn}-\mathrm{N}$ bond lengths $(2.161 \AA)$ of 4 ' agree very well with the experimental values observed for 4 and the recently calculated base-free $\left[\mathrm{Zn}_{2}\right]^{2+}$ dication $(2.46 \AA),{ }^{[25]}$ whereas the calculated value of $\mathbf{1}(2.331 \AA)$ is shorter. ${ }^{[26]}$

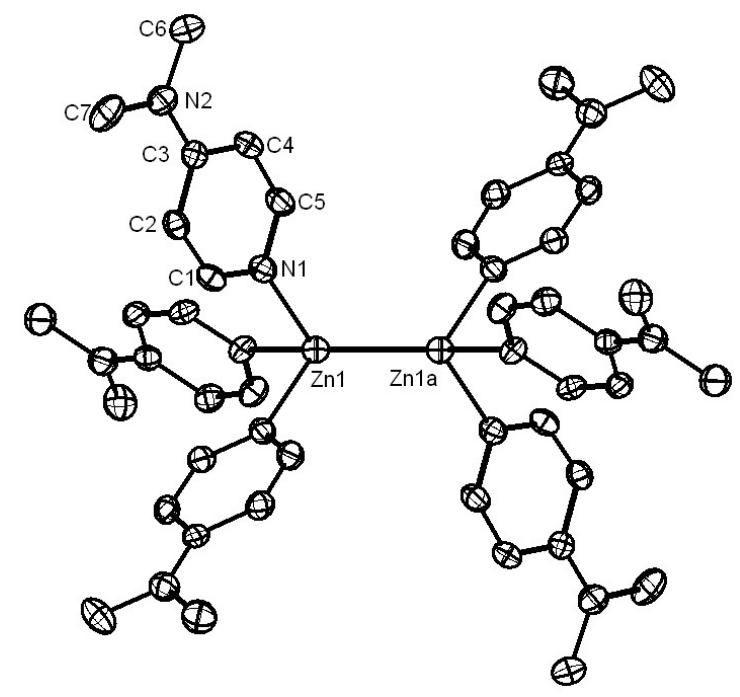

Figure 1. Molecular structure of the $\left[\mathrm{Zn}_{2}(\mathrm{dmap})_{6}\right]^{2+}$ dication of $4 . \mathrm{H}$ atoms and the $\left[\mathrm{Al}\left\{\mathrm{OC}\left(\mathrm{CF}_{3}\right)_{3}\right\}_{4}\right]^{-}$anions are omitted for clarity. Selected bond lengths $[\AA]]$ and angles [ $\left.{ }^{\circ}\right]$ : Zn1-Zn1a 2.419(2), Zn1-N1 2.136(4); N1-Zn1-N2 93.50(16), N1-Zn1-Zn1' 122.75(11).

The existence of the $\left[\mathrm{Zn}_{2}\right]^{2+}$ dication in $\mathrm{Zn} / \mathrm{ZnCl}_{2}$ glasses was exclusively based on Raman spectra, ${ }^{[13]}$ showing a strong absorption band at $175 \pm 5 \mathrm{~cm}^{-1}$. In contrast, no single mode but four distinctive Raman and three IR active modes were identified for $\mathrm{Cp}^{*} \mathrm{Zn}_{2} \mathbf{1}^{[27]}$

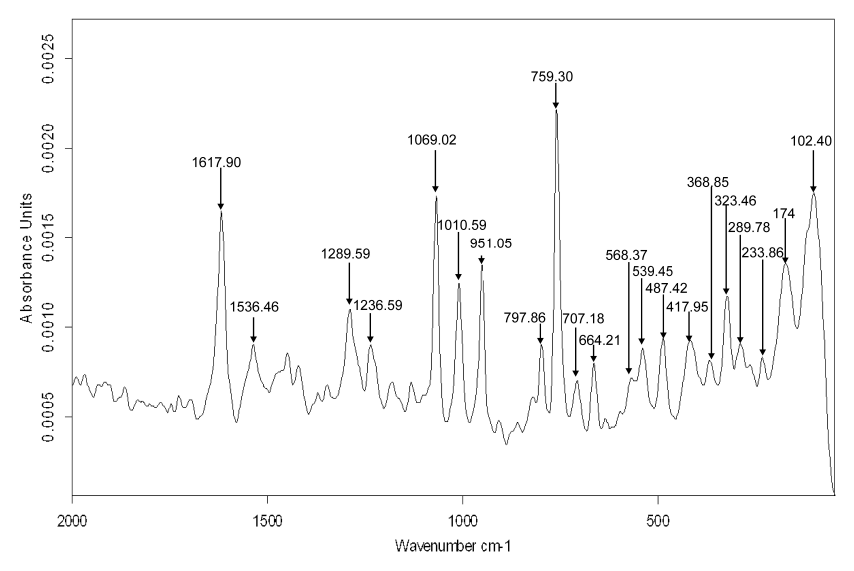

Figure 2. Raman spectrum of 4 between 100 and $2000 \mathrm{~cm}^{-1}(50 \mathrm{~mW}$, $8 \mathrm{~cm}^{-1}$ )

The IR and Raman spectra of $\mathbf{4}$ are somewhat complex due to the presence of the Lewis base dmap and the anion $\left[\mathrm{Al}\left\{\mathrm{OC}\left(\mathrm{CF}_{3}\right)_{3}\right\} 4\right]^{-}$. However, the anion modes were identified by comparison with spectra of known complexes ${ }^{[28]}$ and the dmap modes by comparison with pure dmap and dmap coordinated zinc complexes. ${ }^{[29]}$ In addition, the IR and Raman spectra of $\mathbf{4}$ were simulated using DFT methods.

The IR spectrum of $\mathbf{4}$ shows characteristic strong anion vibrations at 1353,1260,1240,968, 725 and $442 \mathrm{~cm}^{-1}$, which correspond very well with experimental and calculated data. ${ }^{[28]}$ Vibrations at 2962, 1614, 1536, 1065, 1006 and $811 \mathrm{~cm}^{-1}$ agree with calculated bands of the dmap-stabilized dication and can be addressed to vibrations of the dmap group as can be seen when comparing the IR spectra of $\mathbf{4}$ with those of dmap, (dmap) ${ }_{2} \mathrm{ZnCl}_{2}$, and (dmap) ${ }_{2} \mathrm{ZnMe}_{2}$, respectively. ${ }^{[29]}$ Theoretical calculations of $4^{\prime}$ with BP86/def-SV(P) predict three vibrations with larger $\mathrm{Zn}-\mathrm{Zn}$ stretch character, coupled with dmap torsions, at 249, 279, and 305 $\mathrm{cm}^{-1}$, but due to their ag symmetry they should not be visible in the IR spectrum. The calculated force constant of the $\mathrm{Zn}-\mathrm{Zn}$ bond of $1.09 \mathrm{mdyne} / \AA$ is in between that one reported for $\left[\mathrm{Zn}_{2}\right]^{2+}$ in $\mathrm{Zn} / \mathrm{ZnCl}_{2}{ }^{[13]}(0.6 \mathrm{mdyne} / \AA)$ and $\mathrm{Cp}^{*}{ }_{2} \mathrm{Zn}_{2} 1$ (1.42 mdyne/ $\left./ \AA\right) .{ }^{[27]}$.

The experimental Raman spectrum of 4 shows characteristic anion bands at 1290, 798, 759, 539, and $323 \mathrm{~cm}^{-1}$ and typical dmap absorptions. In addition, a vibration observed at $174 \mathrm{~cm}^{-1}$ corresponds very well with the calculated ag-vibration of $4^{\prime}\left(171 \mathrm{~cm}^{-}\right.$ $\left.{ }^{1}\right)$, which exhibits some $\mathrm{Zn}-\mathrm{Zn}$ character. A strong band at $175 \mathrm{~cm}^{-1}$ was reported for the $\mathrm{Zn} / \mathrm{ZnCl}_{2}$ glasses, ${ }^{[12]}$ in which the $\left[\mathrm{Zn}_{2}\right]^{2+}$ dication most likely exists as $\mathrm{Zn}_{2} \mathrm{Cl}_{2}$ unit. Theoretical calculations (BP86/SVP) predict an alg-vibration for $\mathrm{Zn}_{2} \mathrm{Cl}_{2}$ at $194 \mathrm{~cm}^{-1}$.

4 is the first structurally characterized complex containing the $\left[\mathrm{Zn}_{2}\right]^{2+}$ dication. Coordination of the strong Lewis base dmap may have a stabilizing effect for the $\left[\mathrm{Zn}_{2}\right]^{2+}$ unit as is suggested by very recent studies on the stability of base-stabilized, dimeric $\mathrm{Mg}_{2} \mathrm{Cl}_{2} \cdot{ }^{[30]}$ DFT calculations were performed in order to evaluate the stability of the base-stabilized dication. Coulomb explosion of the $\left[\mathrm{Zn}_{2}(\mathrm{dmap})_{6}\right]^{2+}$ dication with subsequent formation of two equivalents of $\left[\mathrm{Zn}(\mathrm{dmap})_{3}\right]^{+}$was found to be strongly endergonic at $298.15 \mathrm{~K}$ both in the gas phase $\left(\Delta \mathrm{H}^{0}=146 \mathrm{~kJ} / \mathrm{mol} ; \Delta \mathrm{G}^{0}=89\right.$ $\mathrm{kJ} / \mathrm{mol})$ as well as in solution $\left(\Delta \mathrm{G}^{0}=183 \mathrm{~kJ} / \mathrm{mol}\right)$, since the Gibbs solvation energies of $\left[\mathrm{Zn}(\mathrm{dmap})_{3}\right]^{+} \quad\left(\begin{array}{lll}-113 & \mathrm{~kJ} / \mathrm{mol}) & \text { and }\end{array}\right.$ $\left[\mathrm{Zn}_{2}(\mathrm{dmap})_{6}\right]^{2+}(-321 \mathrm{~kJ} / \mathrm{mol})$ are strongly exergonic. According to these calculations, the base-stabilized dication is stable in solution. According to NBO analysis, the $\mathrm{Zn}$ atoms in $\left[\mathrm{Zn}_{2}(\mathrm{dmap})_{6}\right]^{2+}$ bear a positive charge of 0.61 (Mulliken: 0.41 ), which is practically equal to the base-free zinc atom $(0.60)$ in $\mathrm{Cp}^{*} \mathrm{Zn}-\mathrm{Zn}(\mathrm{dmap})_{2} \mathrm{Cp}^{*} \mathbf{2}$, in which the dmap-coordinated zinc atom (1.15) carries a significantly higher electronic charge. The NBO analysis (Wiberg bond index) shows a bond order of 0.90 , which is in between the values reported for $1(0.93)$ and $2(0.85)$, respectively. In accordance with the $3 \mathrm{~d}^{10} 4 \mathrm{~s}^{1} 4 \mathrm{p}^{0}$ electron configuration of a $\mathrm{Zn}^{+}$monocation, a molecular orbital study revealed mainly (76\%) s-character of the $\mathrm{Zn}-\mathrm{Zn}$ bond (p: $23 \%$, d: $<1 \%$ ). The Zn-N bond order of 0.23 shows a mainly electrostatic coordination of the dmap ligands. Interestingly, the calculated negative charge of the aromatic $\mathrm{N}$ atom in dmap increases by coordination to the $\mathrm{Zn}$ from -0.52 to -0.63 (Mulliken: -0.12 to 0.25 ). The loss of electron density in the electron lone pair due to coordination seems to be overcompensated mainly by the aromatic $\pi$ system, as the negative charge of the $\mathrm{N}$ atom in the dimethylamino group remains almost unchanged upon coordination (NBO: -0.47 to -0.46; Mulliken: -0.31 to -0.30 ).

\section{Experimental Section}

All manipulations were performed under an $\mathrm{Ar}$ atmosphere. Solvents were dried and degassed prior to use. ${ }^{1} \mathrm{H},{ }^{13} \mathrm{C}\left\{{ }^{1} \mathrm{H}\right\}$ and ${ }^{19} \mathrm{~F}\left\{{ }^{1} \mathrm{H}\right\}$ NMR 
spectra were recorded on a Bruker Avance 500 spectrometer and are referenced to internal $\mathrm{CD}_{2} \mathrm{Cl}_{2}\left({ }^{1} \mathrm{H}: \delta=5.32 ;{ }^{13} \mathrm{C}: \delta=53.5\right)$. IR spectra were recorded on a ALPHA-T FT-IR spectrometer and Raman spectra on a Bruker IFS 55 EQUINOX (with FRA 106 Raman attachment). Melting points were measured in sealed capillaries and were not corrected.

4: $0.16 \mathrm{~g} \mathrm{Cp}^{\star} \mathrm{Zn}-\mathrm{Zn}\left(\mathrm{dmap}_{2}\right) \mathrm{Cp}^{*} 2$ (0.25 mmol) dissolved in $10 \mathrm{~mL}$ of $\mathrm{CH}_{2} \mathrm{Cl}_{2}$ was added at $-30{ }^{\circ} \mathrm{C}$ to a solution of $0.42 \mathrm{~g}$ $\left[\mathrm{H}\left(\mathrm{OEt}_{2}\right)_{2}\right]\left[\mathrm{Al}\left\{\mathrm{OC}\left(\mathrm{CF}_{3}\right)_{3}\right\}_{4}\right](0.5 \mathrm{mmol})$ in $10 \mathrm{~mL}$ of $\mathrm{CH}_{2} \mathrm{Cl}_{2}$ and stirred for $15 \mathrm{~min}$ at $-30{ }^{\circ} \mathrm{C}$. The resulting solution was concentrated in vacuum and stored at $-30{ }^{\circ} \mathrm{C}$. Colorless crystals of $4(0.20 \mathrm{~g}, 0.07$ $\mathrm{mmol}, 28 \%$ based on 2) were obtained after $24 \mathrm{~h}$. The yield of isolated crystals of 4 increased to $64 \%$ when a cold solution $\left(-30{ }^{\circ} \mathrm{C}\right)$ of dmap $(0.12 \mathrm{~g}, 1 \mathrm{mmol})$ in $20 \mathrm{~mL} \mathrm{CH}_{2} \mathrm{Cl}_{2}$ was added after the reaction of 2 and $\left[\mathrm{H}\left(\mathrm{OEt}_{2}\right)_{2}\right]\left[\mathrm{Al}\left\{\mathrm{OC}\left(\mathrm{CF}_{3}\right)_{3}\right\}_{4}\right]$ was completed.

Melting point: $120{ }^{\circ} \mathrm{C}$ (dec.). ${ }^{1} \mathrm{H}-\mathrm{NMR}\left(500 \mathrm{MHz}, \mathrm{CD}_{2} \mathrm{Cl}_{2}, 25^{\circ} \mathrm{C}\right): \delta=$ 3.08 (s, $6 \mathrm{H}, \mathrm{NMe}_{2}$ ), 6.61 (m (AA'XX' spin system, $\left.4 \mathrm{H}, \mathrm{C}(3)-\mathrm{H}\right), 7.89$ $(\mathrm{m}, 2 \mathrm{H}, \mathrm{C}(2)-\mathrm{H}) .{ }^{13} \mathrm{C}\left\{{ }^{1} \mathrm{H}\right\}-N M R\left(125 \mathrm{MHz}, \mathrm{CD}_{2} \mathrm{Cl}_{2}, 25^{\circ} \mathrm{C}\right): \delta=39.5$ $\left(\mathrm{NMe}_{2}\right), 107.8(\mathrm{C}(3)), 121.6\left(\mathrm{~m},{ }^{1} \mathrm{~J}_{\mathrm{C}, \mathrm{F}}=293.51 \mathrm{~Hz}\right), 147.9(\mathrm{C}(2)), 156.2$ $(\mathrm{C}(4)) .{ }^{19} \mathrm{~F}\left\{{ }^{1} \mathrm{H}\right\}(235 \mathrm{MHz}), \mathrm{CD}_{2} \mathrm{Cl}_{2}, 25^{\circ} \mathrm{C}: \delta=-75.8$.

Received: ((will be filled in by the editorial staff))

Published online on ((will be filled in by the editorial staff))

Keywords: Low-valent Complexes - Lewis Acid · Zinc · XRD ·

Theoretical Calculations .

[1] I. Resa, E. Carmona, E. Gutierrez-Puebla, A. Monge, Science 2004 305, 1136-1138. See also the following review article: E. Carmona, A. Galindo, Angew. Chem. 2008, 120, 6626-6637; Angew. Chem. Int. Ed. 2008, 47, 6526-6536.

[2] S. P. Green, C. Jones, A. Stasch, Science 2007, 318, 1754-1757.

[3] a) Z. Zhu, R. C. Fischer, J. C. Fettinger, E. Rivard, M. Brynda, P. P. Power, J. Am. Chem. Soc. 2006, 128, 15068-15069.

[4] Z. Zhu, M. Brynda, R. J. Wright, R. C. Fischer, W. A. Merrill, E Rivard, R. Wolf, J. C. Fettinger, M. M. Olmstead, P. P. Power, J. Am. Chem. Soc. 2007, 129, 10847-10857.

[5] A. Grirrane, I. Resa, A. Rodriguez, E. Carmona, E. Alvarez, E. Gutierrez-Puebla, A. Monge, A. Galindo, D. del Río, R. A. Andersen, J. Am. Chem. Soc. 2007, 129, 693-703.

[6] a) Z. Zhu, R. J. Wright, M. M. Olmstead, E. Rivard, M. Brynda, P. P. Power, Angew. Chem. 2006, 118, 5939-5942; Angew. Chem. Int. Ed. 2006, 45, 5807-5810.

[7] Y. Wang, B. Quillian, P. Wei, H. Wang, X.-J. Yang, Y. Xie, R. B. King, P. v. R. Schleyer, H. F. Schaefer, III, G. H. Robinson, J. Am. Chem. Soc. 2005, 127, 11944-11945.

[8] X.-J. Yang, J. Yu, Y. Liu, Y. Xie, H. F. Schaefer, Y. Liang, B. Wu, Chem. Commun. 2007, 2363-2365.

[9] Y.-C. Tsai, D.-Y. Lu, Y.-M. Lin, J.-K. Hwang, J.-S. K. Yu, Chem. Commun. 2007, 4125-4127.

[10] I. L. Fedushkin, A. A. Skatova, S. Y. Ketkov, O. V. Eremenko, A. V. Piskunov, G. K. Fukin, Angew. Chem. 2007, 119, 4380-4383; Angew. Chem. Int. Ed. 2007, 46, 4302-4305.

[11] J. Yu, X.-J. Yang, Y. Liu, Z. Pu, Q.-S. Li, Y. Xie, H. F. Schaefer, B. Wu, Organometallics 2008, 27, 5800-5805.

[12] a) X. Wang, L. J. Andrews, Phys. Chem. A 2004, 108, 11006-11013. b) T. M. Greene, W. Brown, L. Andrews, A. J. Downs, G. V. Chertihin, N. Runeberg, P. Pyykkö, J. Phys. Chem. 1995, 99, 79257934.

[13] D. H. Kerridge, S. A. Tariq, J. Chem. Soc. A 1967, 1122-1125.

[14] a) M. Kaupp, H. G. von Schnering, Inorg. Chem. 1994, 33, 41794185 ; b) M.-S. Liao, Q.-E. Zhang, W. H. E. Schwarz, Inorg. Chem. 1995, 34, 5597-5605; c) K. K. Pandey, J. Mol. Struct. Theochem 2007, 823, 59-64. See also the following review: M. Hargittai, Chem. Rev. 2000, 100, 2233-2302.

[15] a) K. Seff, Microporous Mesoporous Mater. 2005, 85, 351-354; b) Y. Tian, G.-D. Li, J.-S. Chen, J. Am. Chem. Soc. 2003, 125, 6622-6623; c) S. Zhen, D. Bae, K. Seff, J. Phys. Chem. B 2000, 104, 515-525; d)
F. Rittner, A. Seidel, B. Boddenberg, Microporous Mesoporous Mater. 1998, 24, 127-130.

[16] a) P. Jutzi, N. Burford, Chem. Rev. 1999, 99, 969-990; b) P. H. M. Budzelaar, J. J. Engelberts, J. H. van Lenthe, Organometallics 2003, 22, 1562-1576.

[17] a) F. Thomas, S. Schulz, M. Nieger, Eur. J. Inorg. Chem. 2001, $161-$ 166; b) S. Schulz, M. Nieger, Organometallics 2000, 19, 2640-2643.

[18] D. Schuchmann, U. Westphal, S. Schulz, U. Flörke, D. Bläser, R. Boese, Angew. Chem. 2009, 121, 821-824; Angew. Chem. Int. Ed., 2009, 48, 807-810.

[19] S. P. Green, C. Jones, A. Stasch, Angew. Chem. 2008, 120, 92199223; Angew. Chem. Int. Ed. 2008, 47, 9079-9083.

[20] S. Schulz, D. Schuchmann, U. Westphal, M. Bolte, Organometallics 2009, 28, 1590-1592.

[21] The ${ }^{1} \mathrm{H}$ NMR spectrum of the mother liquor clearly showed resonances of $\mathrm{Cp}^{*} \mathrm{H}$.

[22] Bruker AXS SMART APEX CCD diffractometer $\left(\mathrm{Mo}_{\mathrm{K} \alpha}\right.$ radiation, $\lambda=$ $0.71073 \AA ; T=203(2) 2,153(2) \mathrm{K} 3$ ). The structure was solved by Direct Methods (SHELXS-97, G. M. Sheldrick, Acta Crystallogr. Sect. $A$ 1990, 46, 467) and refined by full-matrix least-squares on $\mathrm{F}^{2}$. Semiempirical absorption corrections were applied. All non-hydrogen atoms were refined anisotropically and hydrogen atoms by a riding model. (SHELXL-97, Program for Crystal Structure Refinement, G. M. Sheldrick, Universität Göttingen, 1997). 4: $\mathrm{C}_{42} \mathrm{H}_{60} \mathrm{~N}_{12} \mathrm{Zn}_{2} \cdot 2$ $\left[\mathrm{C}_{16} \mathrm{~F}_{36} \mathrm{O}_{4} \mathrm{Al}\right], M=2799.04$, colorless crystal $(0.28 \times 0.23 \times 0.16 \mathrm{~mm})$; trigonal, space group $P^{-} 3 ; a=16.9177(6), b=16.9177(6), c=$ 10.4632(4) $\AA ; \alpha=\beta=90^{\circ}, \gamma=120^{\circ}, V=2593.45(16) \AA^{3} ; Z=1 ; \mu=$ $0.666 \mathrm{~mm}^{-1} ; \rho_{\text {ber. }}=1.792 \mathrm{~g} \mathrm{~cm}^{-3} ; 22524$ reflexes $\left(2 \theta_{\max }=48^{\circ}\right), 2687$ unique $\left(R_{\text {int }}=0.0584\right) ; 256$ parameters; largest max. $/ \mathrm{min}$. in the final difference Fourier synthesis $1.698 \mathrm{e} \AA^{-3} /-0.744 \mathrm{e} \AA^{-3}$; max./min. transmission $0.75 / 0.64 ; R_{1}=0.0761(I>2 \sigma(I)), w R_{2}($ all data $)=$ 0.2167 . The crystallographic data (without structure factors) were deposited as ,supplementary publication no. CCDC-723381“ at the Cambridge Crystallographic Data Centre. These data can be obtained free of charge from The Cambridge Crystallographic Data Centre: CCDC, 12 Union Road, Cambridge, CB21EZ (Fax: (+44)1223/336033; E-mail: deposit@ccdc.cam-ak.uk).

[23] This causes a disc-like density distribution perpendicular to the respective Al-O bonds, indicating that the Al-O-C bonds are not linear The disorder could not be reasonably resolved and is expected to be transferred to the $\mathrm{C}$-atoms of the $\mathrm{CF}_{3}$ groups, even though this does not show up. Quite commonly, the fluorine atoms of the $\mathrm{CF}_{3}$ groups are also disordered.

[24] DFT calculations were carried out with Turbomole and Gaussian03 (M.J. Frisch, et al. Gaussian 03, Revision D.02; Gaussian Inc.: Pittsburgh, PA, 2003, complete reference is given in the supplement) Geometry optimization, vibrational analysis and calculation of the $\mathrm{Zn}-\mathrm{Zn}$ bond force constant was performed at BP86/def-SV(P) level. Bond analysis was done at the B3LYP/def-SVP level. Details are given in the supplement.

[25] M. R. Philpott, Y. Kawazoe, Chem. Phys. 2006, 327, 283-290.

[26] D. del Río, A. Galindo, I. Resa, E. Carmona, Angew. Chem. 2005, 117, 1270-1273; Angew. Chem. Int. Ed. 2005, 44, 1244-1247.

[27] D. del Rio, I. Resa, A. Rodriguez, L. Sánchez, R. Köppe, A. J. Downs, C. Y. Tang, E. Carmona, J. Phys. Chem. A 2008, 112, 10516-10525. Four Raman active modes $\left(593,382,229\right.$ and $\left.107 \mathrm{~cm}^{-1}\right)$ and three IR active modes $\left(591,318,158 \mathrm{~cm}^{-1}\right)$ were predicted and experimentally observed (Raman: 590.8, 373.6, 236.0, $130.7 \mathrm{~cm}^{-1}$; IR: 586.8, 320.6 $\left.\mathrm{cm}^{-1}\right)$. The $158 \mathrm{~cm}^{-1}$ transition in the IR spectrum was denied due to the absorption of the CsI plates below $200 \mathrm{~cm}^{-1}$. Earlier theoretical studies agreed with the finding, that no single mode can be addressed to the $\mathrm{Zn}-\mathrm{Zn}$ stretching vibration. a) S. L. Richardson, T. Baruah, M. R. Pederson, Chem. Phys. Lett. 2005, 415, 141-145; b) J. W. Kress, J. Phys. Chem. A 2005, 109, 7757-7763.

[28] I. Krossing, A. Reisinger, Eur. J. Inorg. Chem. 2005, 1979-1989.

[29] Full details of the experimental and calculated IR and Raman spectra of 4, $\left[\mathrm{Al}\left\{\mathrm{OC}\left(\mathrm{CF}_{3}\right)_{3}\right\}_{4}\right]^{-}$, (dmap $)_{2} \mathrm{ZnCl}_{2}$, (dmap) $)_{2} \mathrm{ZnMe}_{2}$ and pure dmap are given in the electronic supplement.

[30] R. Köppe, P. Henke, H. Schnöckel, Angew. Chem. 2008, 120, 88688872; Angew. Chem. Int. Ed. 2008, 47, 8740-8744. 


\section{Entry for the Table of Contents}

\section{Base-stabilized $\left[Z n_{2}\right]^{2+}$}

Stephan Schulz, ${ }^{*}$ Daniella Schuchmann, Ingo Krossing, ${ }^{*}$ Daniel Himmel, Dieter Bläser and Roland Boese

Page - Page

Structural Characterization of a BaseStabilized $\left[\mathrm{Zn}_{2}\right]^{2+}$ Dication

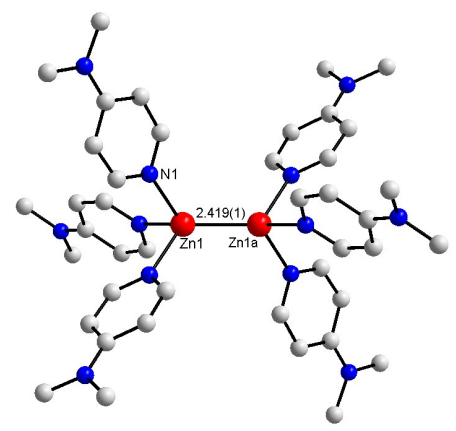

First structural characterization of a base-stabilized $\left[Z_{2}\right]^{2+}$ dication, which was obtained from the reaction of $\mathrm{Cp}^{*}{ }_{2} \mathrm{Zn}_{2}$ (dmap) 2 with two equivalents $\left[\mathrm{H}\left(\mathrm{OEt}_{2}\right)_{2}\right]\left[\mathrm{Al}\left\{\mathrm{OC}\left(\mathrm{CF}_{3}\right)_{3}\right\}_{4}\right]$. 


\section{DuEPublico}

This text is made available via DuEPublico, the institutional repository of the University of Duisburg-Essen. This version may eventually differ from another version distributed by a commercial publisher.

DOI: $\quad 10.1002 /$ anie.200902202

URN: urn:nbn:de:hbz:464-20201030-111143-6

This is the peer reviewed version of the following article: Angew. Chem. Int. Ed., 2009, 48, 5748-5751, which has been published in final form at:

https://doi.org/10.1002/anie.200902202

All rights reserved. 